Mai Ohsawa · Masaharu Kotani · Youichi Tajima

Daisuke Tsuji · Yasuhiro Ishibashi · Aya Kuroki

Kohji Itoh · Kazuhiko Watabe · Kazunori Sango

Shoji Yamanaka · Hitoshi Sakuraba

\title{
Establishment of immortalized Schwann cells from Sandhoff mice and corrective effect of recombinant human $\beta$-hexosaminidase $A$ on the accumulated GM2 ganglioside
}

Received: 2 June 2005 / Accepted: 11 July 2005 / Published online: 23 September 2005

(c) The Japan Society of Human Genetics and Springer-Verlag 2005

\begin{abstract}
We have established spontaneously immortalized Schwann cell lines from dorsal root ganglia and peripheral nerves of Sandhoff mice. One of the cell lines exhibited genetically and biochemically distinct features of Sandhoff Schwann cells. The enzyme activities toward 4-methylumbelliferyl $\quad N$-acetyl- $\beta$-D-glucosamine $\quad(\beta$ hexosaminidases $\mathrm{A}, \mathrm{B}$, and $\mathrm{S}$ ) and 4-methylumbelliferyl $N$-acetyl- $\beta$-D-glucosamine-6-sulfate ( $\beta$-hexosaminidases $A$ and S) were decreased, and GM2 ganglioside accumulated in lysosomes of the cells. Incorporation of re-
\end{abstract}

M. Ohsawa $\cdot$ M. Kotani $\cdot$ Y. Tajima $\cdot$ D. Tsuji $\cdot$ Y. Ishibashi A. Kuroki · K. Itoh $\cdot$ K. Watabe $\cdot$ H. Sakuraba

CREST, JST, Kawaguchi, Japan

M. Ohsawa $\cdot$ M. Kotani $\cdot$ Y. Tajima $\cdot$ H. Sakuraba $(\bowtie)$ Department of Clinical Genetics,

The Tokyo Metropolitan Institute of Medical Science, Tokyo Metropolitan Organization for Medical Research, 3-18-22 Honkomagome, Bunkyo-ku, Tokyo 113-8613, Japan E-mail: sakuraba@rinshoken.or.jp

Tel.: + 81-3-38232105

Fax: + 81-3-38236008

D. Tsuji $\cdot$ Y. Ishibashi $\cdot$ A. Kuroki $\cdot$ K. Itoh Department of Medicinal Biotechnology, Institute for Medicinal Resources,

Graduate School of Pharmaceutical Sciences,

The University of Tokushima, Tokushima, Japan

K. Watabe

Department of Molecular Neuropathology, Tokyo Metropolitan Institute for Neuroscience,

Tokyo Metropolitan Organization for Medical Research,

Tokyo, Japan

\section{K. Sango}

Department of Developmental Morphology, Tokyo Metropolitan Institute for Neuroscience, Tokyo Metropolitan Organization for Medical Research,

Tokyo, Japan

S. Yamanaka

Department of Pathology, School of Medicine,

Yokohama City University, Yokohama, Japan combinant human $\beta$-hexosaminidase isozymes expressed in Chinese hamster ovary cells into the cultured Sandhoff Schwann cells via cation-independent mannose 6phosphate receptors was found, and the incorporated $\beta$ hexosaminidase A degraded the accumulated GM2 ganglioside. The established Sandhoff Schwann cell line is useful for investigation and development of therapies for Sandhoff disease.

Keywords Sandhoff disease $\cdot \beta$-Hexosaminidase · GM2 ganglioside $\cdot$ Schwann cell $\cdot$

Lysosomal disease $\cdot$ Enzyme replacement therapy

\section{Introduction}

$\beta$-Hexosaminidase (Hex; EC 3. 2. 1. 52) is a lysosomal glycosyl hydrolase that catalyzes the hydrolysis of $\beta-1,4-$ linked $N$-acetyl hexosamine residues at the nonreducing ends of glycoconjugates. The human $H E X A$ and $H E X B$ genes code for the $\alpha$-subunit and $\beta$-subunit of Hex, which dimerize to produce two major isozymes$\beta$-hexosaminidase $\mathrm{A}$ (Hex A, $\alpha \beta$ heterodimer) and $\beta$-hexosaminidase $\mathrm{B}$ (Hex B, $\beta \beta$ homodimer) - and a minor, unstable isozyme, $\beta$-hexosaminidase $\mathrm{S}(\operatorname{Hex} \mathrm{S}, \alpha \alpha$ homodimer). All of the Hex isozymes basically degrade terminal $\mathrm{N}$-acetylgalactosamine (GalNAc) and $\mathrm{N}$-acetylglucosamine (GlcNAc) residues while Hex A and Hex $\mathrm{S}$ cleave off terminal $\mathrm{N}$-acetylglucosamine-6-sulfate residues, and only Hex A among the three isozymes can degrade GM2 ganglioside by acting on a complex of GM2 ganglioside and the GM2 activator encoded by GM2A (Gravel et al. 2001). The 4-methylumbelliferyl $N$ acetyl- $\beta$-D-glucosamine (MUG) and 4-methylumbelliferyl $N$-acetyl- $\beta$-D-glucosamine-6-sulfate (MUGS) are usually used as artificial substrates for enzyme assaying of the total Hex isozymes and for that of Hex A and Hex $\mathrm{S}$, respectively. The defect of the $H E X B$ gene causes 
Sandhoff disease with simultaneous deficiencies of both Hex A and Hex B, which result in storage of GM2 ganglioside in the nervous system and accumulation of oligosaccharides and glycoproteins with GlcNAc residues at the nonreducing ends of the sugar chains in the extraneuronal tissues. Sandhoff disease involves progressive neurological disorders and exhibits a wide clinical spectrum from the severe infantile form (classical Sandhoff disease), which is of early onset and fatal before the age of 4 years, to the late onset and less severe form, which allows survival into childhood or adulthood (subacute and chronic forms and atypical Sandhoff disease). Patients with the severe infantile form of Sandhoff disease develop progressive psychomotor delay, muscular weakness, hypotonia, visual disturbance, cherry-red spots, seizures, macrocephaly, and hepatosplenomegaly. Patients with the milder, late-onset form of Sandhoff disease develop dystonia, ataxia, incoordination, muscle wasting, and weakness. However, the common pathological and biochemical changes in the various clinical forms of Sandhoff disease are ultrastructurally identified membranous cytoplasmic inclusion bodies and accumulation of GM2 ganglioside, respectively, in the central and peripheral nervous systems (Gravel et al. 2001).

Recently, a mouse model of Sandhoff disease was created through the targeted disruption of the Hexb gene, which encodes mouse Hex $\beta$-subunit (Sango et al. 1995; Phaneuf et al. 1996). Sandhoff mice exhibit progressive neurological disorders consistent with the corresponding human disease, and morphological changes specific for this disease are found in neurons of the cerebrum, cerebellum, spinal cord, dorsal root ganglia (DRG) and visceral organs, satellite cells, and Schwann cells (Sango et al. 1995, 2002), suggesting storage of GM2 ganglioside in these neuronal cells.

Enzyme replacement therapy (ERT) has been introduced for lysosomal diseases, including Gaucher disease (Barton et al. 1991), Fabry disease (Schiffmann et al. 2000; Eng et al. 2001), and mucopolysaccharidosis (MPS) I (Wraith et al. 2004); clinical trials for Pompe disease (Van den Hout et al. 2004; Klinge et al. 2005), MPS II (Muenzer et al. 2002), and MPS VI (Harmatz et al. 2004) are underway. Furthermore, therapeutic experiments have also been performed for other lysosomal diseases associated with neurological disorders, including Sandhoff disease (Dobrenis et al. 1992). In these experiments, cell lines possessing distinct phenotypes of the nervous system are required to detect cleavage of the accumulated substances from the neuronal cells after treatment. However, such kinds of cell lines had not been established yet for Sandhoff disease. They would be useful for clarification of the pathogenesis of Sandhoff disease and the development of therapies for the disease.

In this study, we established spontaneously immortalized Schwann cell lines from DRG and peripheral nerves of Sandhoff mice and examined their uptake of the recombinant Hex isozymes produced by Chinese hamster ovary $(\mathrm{CHO})$ cell lines simultaneously express- ing the human $H E X A$ and $H E X B$ genes and degradation of the accumulated GM2 ganglioside. The effects of the recombinant Hex isozymes on the cultured Sandhoff Schwann cells were compared with those on cultured fibroblasts from a patient with Sandhoff disease.

\section{Materials and methods}

Animals and cell culture

C57BL/6 Sandhoff mice homozygous for the disrupted Hexb gene (Sango et al. 1995) were used in this experiment according to the rules drawn up by the Animal Care Committee of our institute. Primary and long-term cultures of DRG and adjacent peripheral nerves collected from 8-week-old Sandhoff mice were performed and spontaneously immortalized Schwann cells were obtained, as previously described (Watabe et al. 1990, 1994, 1995, 2001). Among them, an established Schwann cell line from a Sandhoff mouse $(1113 \mathrm{C} 1)$ was cultured in Iscove's modified Dulbecco's minimum essential medium supplemented with $5 \%$ fetal calf serum (FCS), 50 units $/ \mathrm{ml}$ penicillin, and $50 \mu \mathrm{g} / \mathrm{ml}$ streptomycin at $37^{\circ} \mathrm{C}$ under a $5 \% \mathrm{CO}_{2}-95 \%$ air mixture. Spontaneously immortalized Schwann cells were obtained from CD-1 (ICR) wild-type mice, and an established cell line (IMS32) was used as a control (Watabe et al. 1995).

Cultured skin fibroblasts from a patient with Sandhoff disease and a normal subject were established and maintained in our laboratory. The study involving the cultured fibroblasts was approved by the Ethical Committee of our institution. The cells were cultured in Ham's F-10 medium supplemented with $10 \%$ FCS and antibiotics at $37^{\circ} \mathrm{C}$ in a humidified incubator flushed continuously with a $5 \% \mathrm{CO}_{2}-95 \%$ air mixture.

\section{Polymerase chain reaction}

Confirmation of the genotype of the established cultured Schwann cells was performed by means of polymerase chain reaction (PCR), as previously described (Sango et al. 2002). Reverse transcription followed by PCR (RTPCR) was performed to identify Schwann-cell-associated molecules, i.e., $\mathrm{S} 100, \mathrm{p} 75^{\mathrm{NTR}}$, L1, peripheral myelin protein zero (P0), peripheral myelin protein-22 (PMP-22), and growth-associated protein-43 (GAP-43), as described elsewhere (Mirsky and Jessen 1999; Watabe et al. 2001, 2003).

Immunocytochemical analysis of Schwann-cell-associated markers

To characterize the established cultured Schwann cells, immunocytochemical analysis of S100, laminin, and glial fibrillary acidic protein (GFAP) was performed, as described previously (Watabe et al. 1995, 2003). 
Enzyme assays and protein determination

Total Hex (Hex A, Hex B, and Hex S) activity in cultured cells was determined with MUG (Nacalai Tesque, Kyoto, Japan) as a substrate (Suzuki 1987). Enzyme activity for Hex A and Hex $\mathrm{S}$ was determined with MUGS (HSC Research Development Co., Toronto, Canada) as a substrate, according to the manufacturer's method. Protein determination was performed with a Bio-Rad dye-binding assay kit (Bio-Rad, Hercules, CA, USA) using bovine serum albumin as a standard.

Preparation of the recombinant human Hex isozymes produced in $\mathrm{CHO}$ cells

A $\mathrm{CHO}$ cell line simultaneously expressing the human Hex $\alpha$-subunit and $\beta$-subunit were established by means of cointroduction of the human HEXA and HEXB cDNAs, as described elsewhere (Sakuraba et al. 2005). The CHO cells stably expressing Hex isozymes, including Hex A, Hex B, and Hex S, were cultured in serumfree Ham's F-10 medium. After 3 days of incubation, the culture medium was harvested and used as the conditioned medium.

Administration of the Hex isozymes to cultured mouse Sandhoff Schwann cells and cultured human Sandhoff fibroblasts

To examine the uptake of the Hex isozymes and cleavage of the accumulated GM2 ganglioside by the incorporated Hex A, cultured mouse Sandhoff Schwann cells and cultured human Sandhoff fibroblasts were cultured on 6-well plates in the conditioned medium containing Hex isozymes in the presence or absence of $5 \mathrm{mM}$ mannose 6-phosphate (M6P). Because Hex A is heatlabile, a half volume of the culture medium was replaced daily by the same volume of fresh medium containing the same levels of MUG-degrading and MUGSdegrading activities, and then the cultured cells were harvested for enzyme assays or fixed with $4.5 \%$ paraformaldehyde for an immunocytochemical analysis of intracellular GM2 ganglioside, as described below.

Immunocytochemical analysis of intracellular GM2 ganglioside

To examine the accumulation and localization of GM2 ganglioside in the cultured cells, double immunostaining with a monoclonal anti-GM2 ganglioside antibody (IgM isotype; Kotani et al. 1992) and affinity-purified goat polyclonal antibodies against lysosome-associated membrane protein-1 (LAMP-1) (IgG isotype; Santa Cruz Biochemistry, Santa Cruz, CA, USA) was performed, as described previously (Sakuraba et al. 2002).
The stained cells were examined under a microscope (Axiovert 100M; Carl Zeiss, Oberkochen, Germany) equipped with a confocal laser scanning imaging system (LSM510; Carl Zeiss).

\section{Results}

Characterization of the established Schwann cells derived from a Sandhoff mouse

The Schwann cell lines established from Sandhoff mice were spindle-shaped and not contact-inhibited. One of the cell lines, designated as $1113 \mathrm{C} 1$, was used in this study. To determine the genotype of the established Schwann cells, a genomic DNA fragment of 114-bp in the Hexb wild-type locus and a 219-bp DNA fragment in the targeted locus were amplified by means of PCR, according to the method described previously (Sango et al. 1995). As shown in Fig. 1, a 219-bp DNA fragment in the targeted locus was detected for $1113 \mathrm{C} 1$ while a 114-bp band in the wild-type locus was observed for IMS32. The results confirmed that $1113 \mathrm{C} 1$ is genetically homozygous for the disrupted Hexb gene.

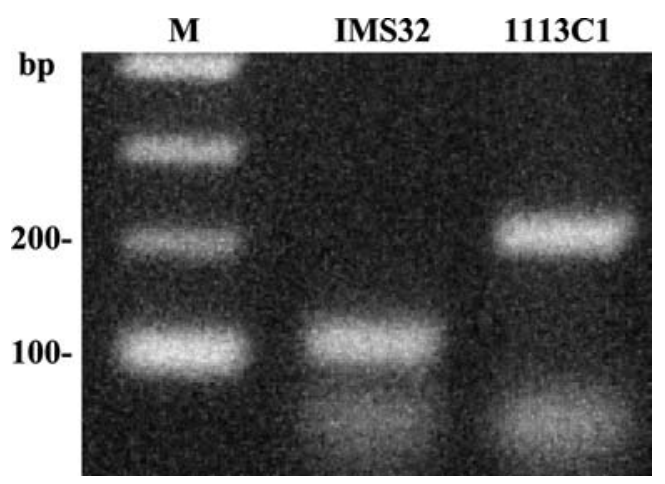

Fig. 1 Genomic PCR analysis of Hexb in IMS32 and $1113 \mathrm{C} 1$ cells. PCR amplification from IMS32 cells results in a 114-bp fragment and that from $1113 \mathrm{C} 1$ cells in a 219-bp fragment

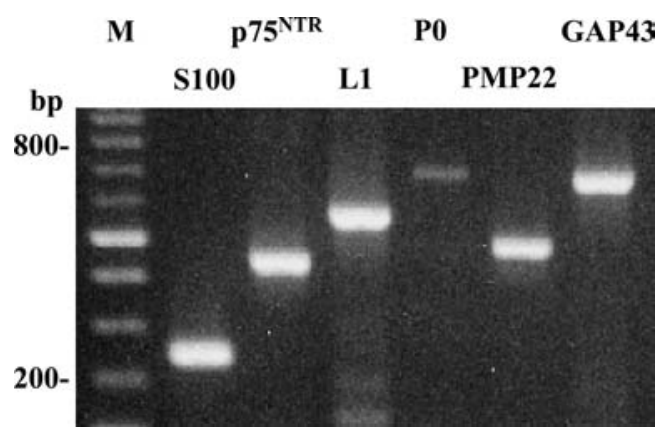

Fig. 2 RT-PCR analysis of $1113 \mathrm{C} 1$ cells. The 100-bp DNA size markers $(M)$ and amplified PCR fragments of $\mathrm{S} 100, \mathrm{p} 75^{\mathrm{NTR}}, \mathrm{L} 1$, P0, PMP22, and GAP43 
Fig. 3 Phase-contrast and immunofluorescence microscopy of $1113 \mathrm{C} 1$ cells. Phase-contrast microscopy of living cells (a), and immunofluorescence for S100 (b), laminin (c), and GFAP (d). Bars, $50 \mu \mathrm{m}$
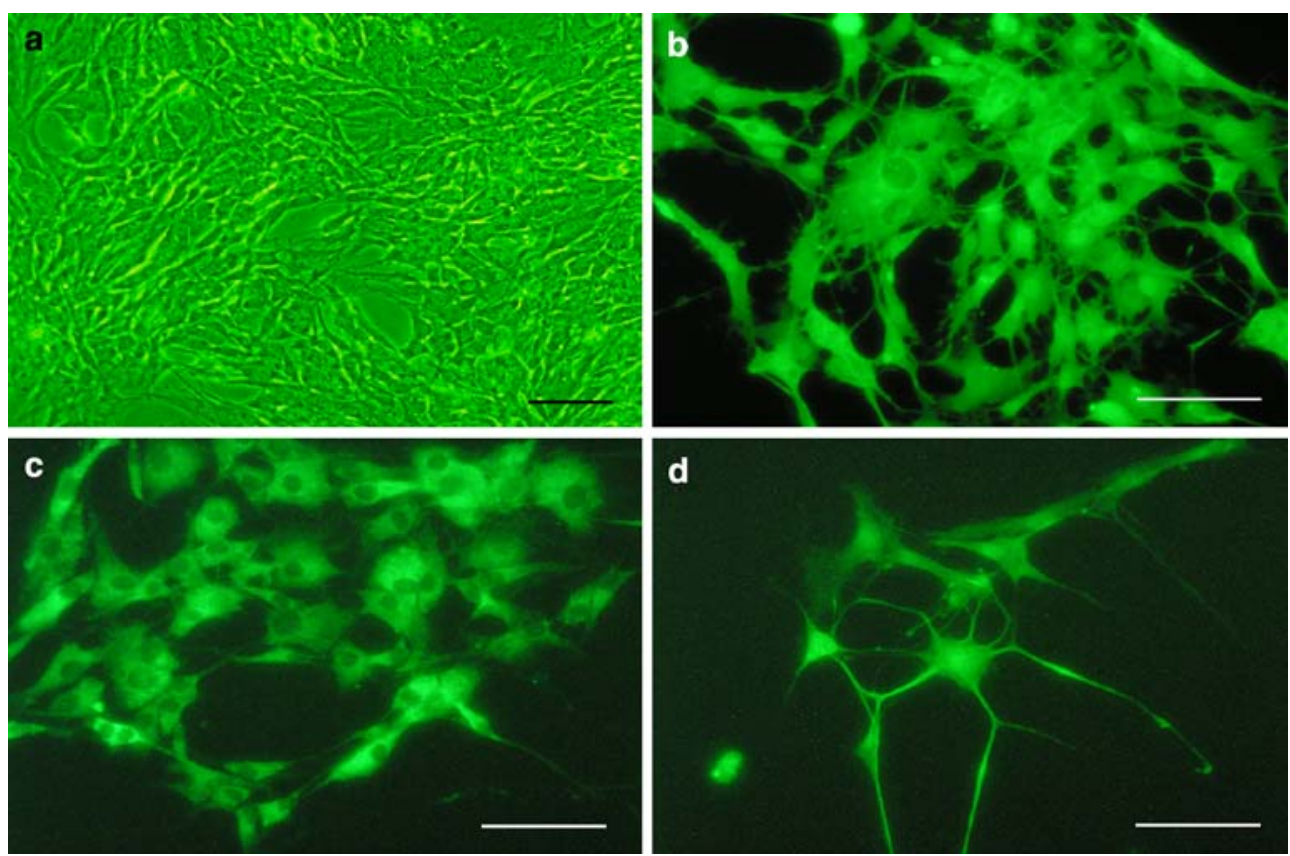

RT-PCR demonstrated mRNA expression of S100, p $75^{\mathrm{NTR}}$, L1, P0, PMP22, and GAP43 (Fig. 2), and immunocytochemical analysis also revealed protein expression of S100, laminin, and GFAP in 1113C1 (Fig. 3). These results indicate the distinct Schwann cell phenotype of $1113 \mathrm{C} 1$.

To investigate the localization and accumulation of GM2 ganglioside in the cultured Sandhoff Schwann cells, double staining was performed with a monoclonal antibody for GM2 ganglioside and polyclonal antibodies for LAMP-1 as a lysosomal marker. Intense granular immunofluorescence for GM2 ganglioside was observed in $1113 \mathrm{C} 1$ while only faint fluorescence was found in IMS32, and the localization was coincident with that of LAMP-1 (Fig. 4a). Enhanced immunofluorescence for LAMP-1 was also observed in $1113 \mathrm{C} 1$. These results suggested increased and enlarged lysosomes containing abundant gangliosides in Schwann cells derived from a Sandhoff mouse. The intensity of the immunofluorescence for GM2 ganglioside in $1113 \mathrm{C} 1$ was almost the same as that in cultured human Sandhoff fibroblasts (Fig. 4b). The MUGS-degrading and MUG-degrading activities in $1113 \mathrm{Cl}$ were $19 \%$ and $5 \%$ of the control values, respectively (Table 1 ). The MUGS-degrading and MUG-degrading activities are slightly higher than those for cultured human Sandhoff fibroblasts (Table 1).

Enzyme replacement effect of recombinant human Hex isozymes on the intracellular Hex activities and cleavage of GM2 ganglioside in cultured mouse Sandhoff Schwann cells

We investigated the uptake of the recombinant human Hex isozymes by mouse Sandhoff Schwann cells in culture and compared it with that in the case of cultured human Sandhoff fibroblasts. The conditioned medium from the CHO transformants expressing the human $\alpha$-subunit and $\beta$-subunit cDNAs was administered to mouse Sandhoff Schwann cells and human Sandhoff fibroblasts. The MUGS-degrading and MUG-degrading activities in the conditioned medium were 299 and $758 \mathrm{nmol} / \mathrm{h}$ per milliliter, respectively. As shown in Table 1, the intracellular MUGS-degrading and MUG-degrading activities in the mouse Sandhoff Schwann cells were increased by $30 \%$ and $33 \%$ compared with the normal control values after 3 days of culture in the conditioned medium while those in the human Sandhoff fibroblasts were restored by $66 \%$ and $99 \%$, respectively. The uptake of the recombinant Hex isozymes was inhibited in the presence of $5 \mathrm{mM}$ M6P in the culture medium.

We also investigated the effect of incorporated Hex A on the degradation of GM2 ganglioside accumulated in the mouse Sandhoff Schwann cells (Fig. 5a) and human Sandhoff fibroblasts (Fig. 5b). The GM2 ganglioside accumulated in the mouse Sandhoff Schwann cells was cleaved on 3 days of culture with the conditioned medium containing Hex A as well as in the human Sandhoff fibroblasts. The enhanced immunofluorescence for LAMP-1 was also normalized by this procedure. The effect was inhibited by the addition of M6P to the culture medium.

\section{Discussion}

In this study, we established a spontaneously immortalized Schwann cell line, 1113C1, from DRG and peripheral nerves of Sandhoff mice. The 1113C1 cells possess the disrupted Hexb gene allele and exhibit a 


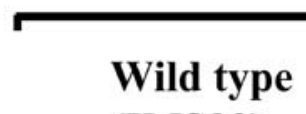

(IMS32)

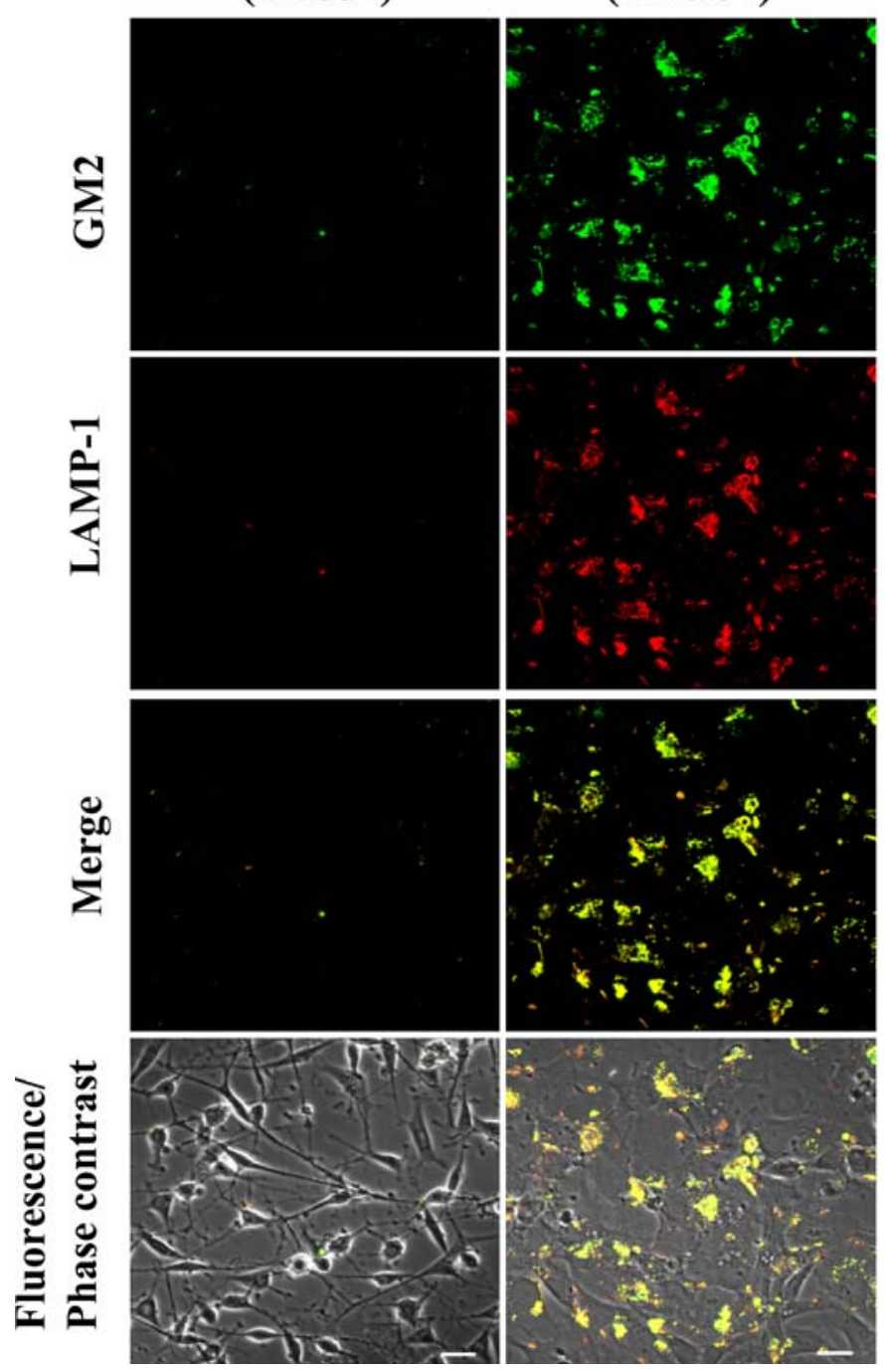

Fig. 4 Immunocytochemical analysis of intracellular GM2 ganglioside. Double staining of cultured mouse Schwann cells (a) and human fibroblasts (b) was carried out using a monoclonal antibody for GM2 ganglioside (GM2, green) and polyclonal antibodies for

distinct Schwann cell morphology and biochemical phenotypes such as S100, p $75^{\mathrm{NTR}}$, L1, P0, PMP-22, GAP-43, laminin, and GFAP, as shown on RT-PCR and/or immunocytochemical analysis. Moreover, immunocytochemical analysis revealed the accumulation of GM2 ganglioside in lysosomes of $1113 \mathrm{C} 1$ cells as well as in those of cultured human Sandhoff fibroblasts. The reason the $1113 \mathrm{C} 1$ cells have residual MUGSdegrading and MUG-degrading activities has not been clarified yet. However, as the disruption of the mouse Hex $\beta$-subunit gene and the accumulation of GM2 ganglioside due to decreased Hex A activity are characterized in this cell line, the residual activity must be mainly resulted from b

\section{Human fibroblasts}
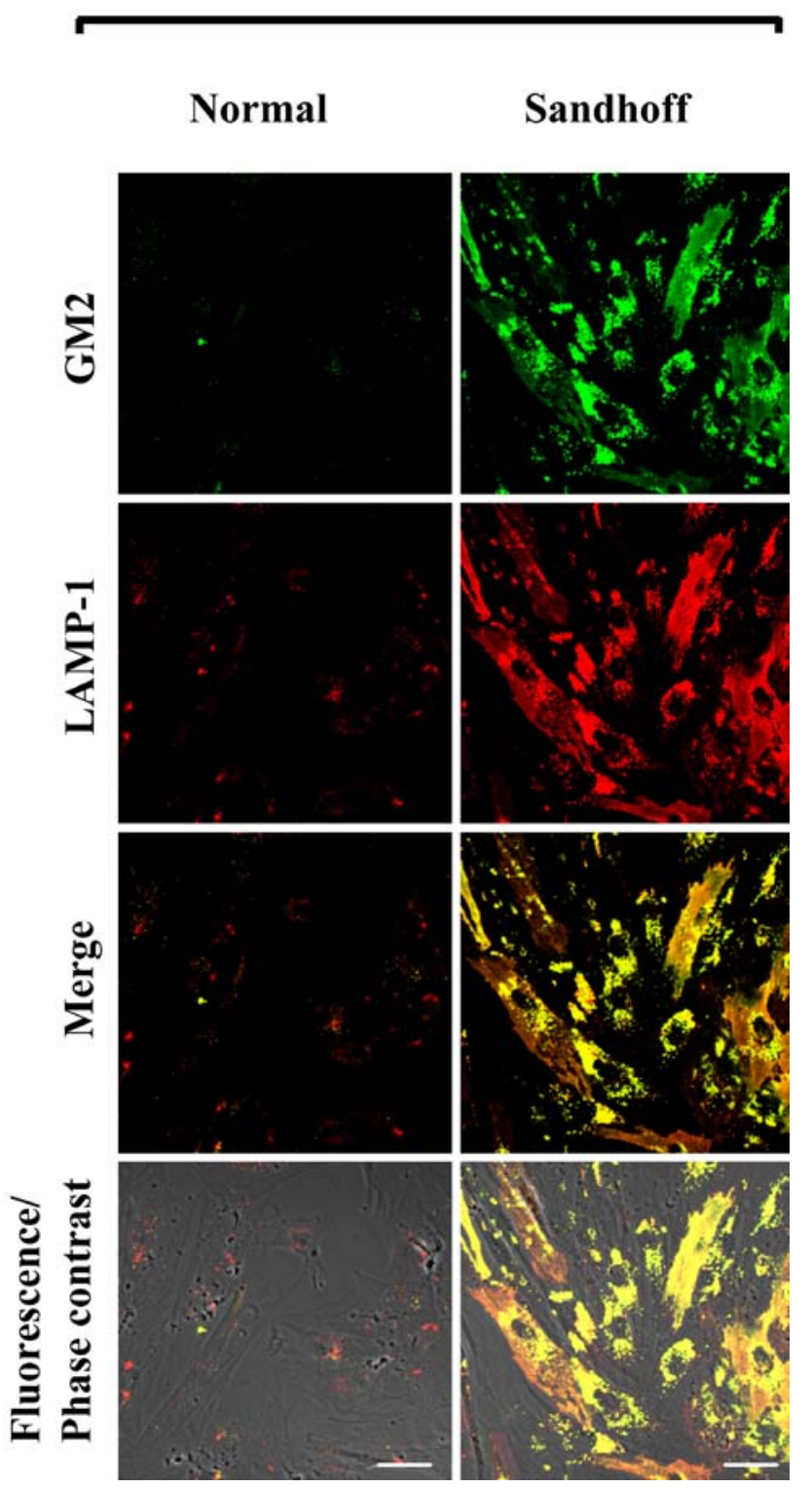

LAMP-1 (LAMP-1, red). Overlapped images with these two fluorescent probes are shown in yellow (Merge). Fluorescence/ Phase contrast shows overlapped Merge and phase-contrast images. Bars, $50 \mu \mathrm{m}$

Hex S ( $\alpha \alpha$ homodimer). Culture condition and/or tissue specificity might influence the formation of $\alpha \alpha$ homodimer. Considering the analytical data, the $1113 \mathrm{C} 1$ cell lines are thought to be useful for clarifying the pathophysiology of Sandhoff disease and for examining effects in the therapeutic experiments on this disease.

We obtained the recombinant Hex isozymes from the $\mathrm{CHO}$ cell line coexpressing the human Hex $\alpha$-subunit and $\beta$-subunit cDNAs. The MUGS-degrading and MUGdegrading activities increased in $1113 \mathrm{C} 1$ cells on culturing them in conditioned medium containing the expressed Hex isozymes although the degrees of the increases of the enzyme activities were lower than that in the cultured 
Table 1 Restoration of MUGS-degrading and MUG-degrading activities in cultured mouse Sandhoff Schwann cells and cultured human Sandhoff fibroblasts after addition of conditioned media from the transformed Chinese hamster ovary (CHO) cell lines

\begin{tabular}{|c|c|c|c|c|c|c|}
\hline & Conditioned medium & $5 \mathrm{mM}$ M6P & \multicolumn{2}{|c|}{ MUGS-degrading activity } & \multicolumn{2}{|c|}{ MUG-degrading activity } \\
\hline \multicolumn{7}{|c|}{ Cultured mouse Schwann cells } \\
\hline Wild type (IMS32) & - & - & 992 & 100 & 2491 & 100 \\
\hline \multirow[t]{3}{*}{ Sandhoff $(1113 \mathrm{C} 1)$} & - & - & 188 & 19 & 177 & 5 \\
\hline & + & - & 300 & 30 & 811 & 33 \\
\hline & + & + & 203 & 20 & 316 & 13 \\
\hline \multirow[t]{3}{*}{ Sandhoff } & - & - & 52 & 5 & 63 & 1 \\
\hline & + & - & 649 & 66 & 4201 & 99 \\
\hline & + & + & 92 & 9 & 381 & 9 \\
\hline
\end{tabular}

Cultured mouse Sandhoff Schwann cells (1113C1) and cultured human Sandhoff fibroblasts were cultured with conditioned media containing Hex isozymes from CHO transformants, as described in Materials and methods. Some experiments were performed in the presence of $5 \mathrm{mM}$ M6P. After 3 days, the cells were harvested, and MUGS-degrading and MUG-degrading activities were measured. As a control, IMS32 cells from a wild-type mouse and human cultured fibroblasts from a normal subject were used. $(n=2)$

a

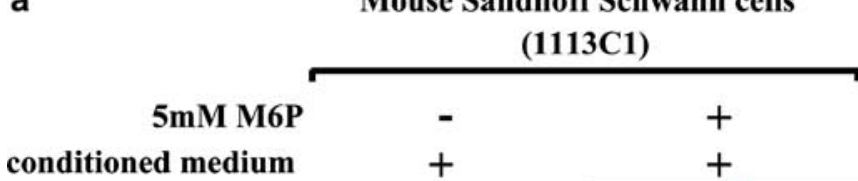

conditioned medium
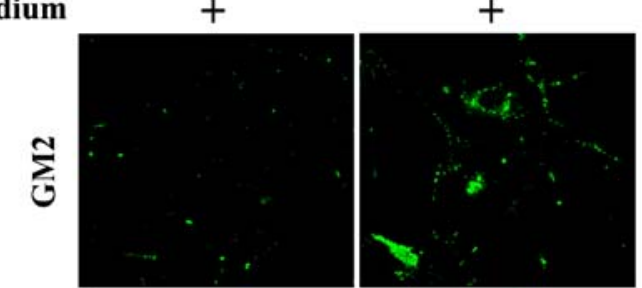

\section{$\sum_{-1}^{1}$}
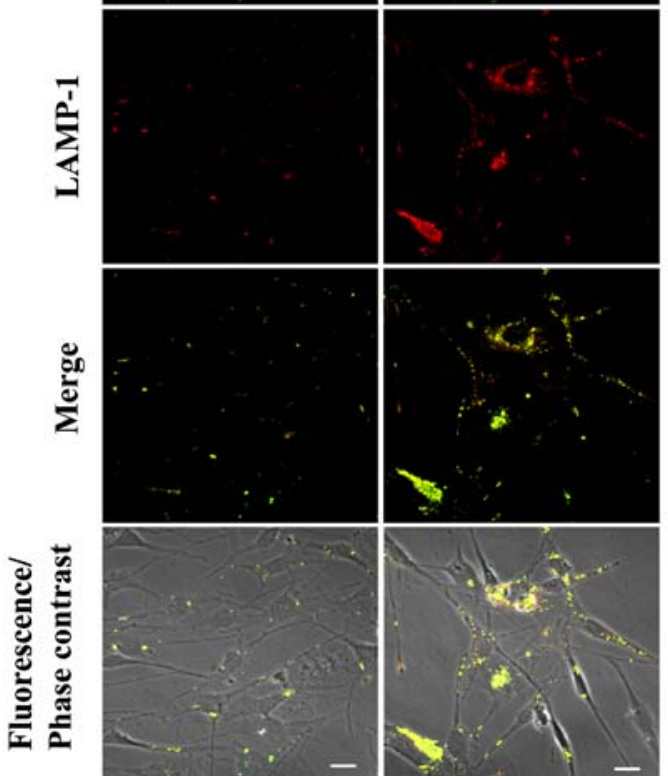

Fig. 5 Administration of the recombinant human Hex isozymes to mouse Sandhoff Schwann cells and human Sandhoff fibroblasts. Cultured mouse Schwann cells (a) and human fibroblasts (b) with Sandhoff disease were stimulated with the conditioned media containing Hex isozymes from Chinese hamster ovary $(\mathrm{CHO})$ transformants for 3 days. Double staining b

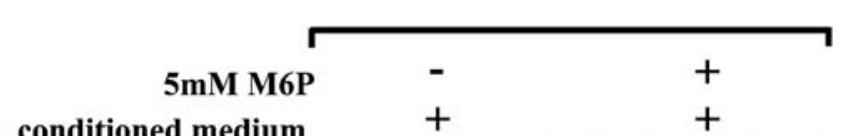

conditioned medium
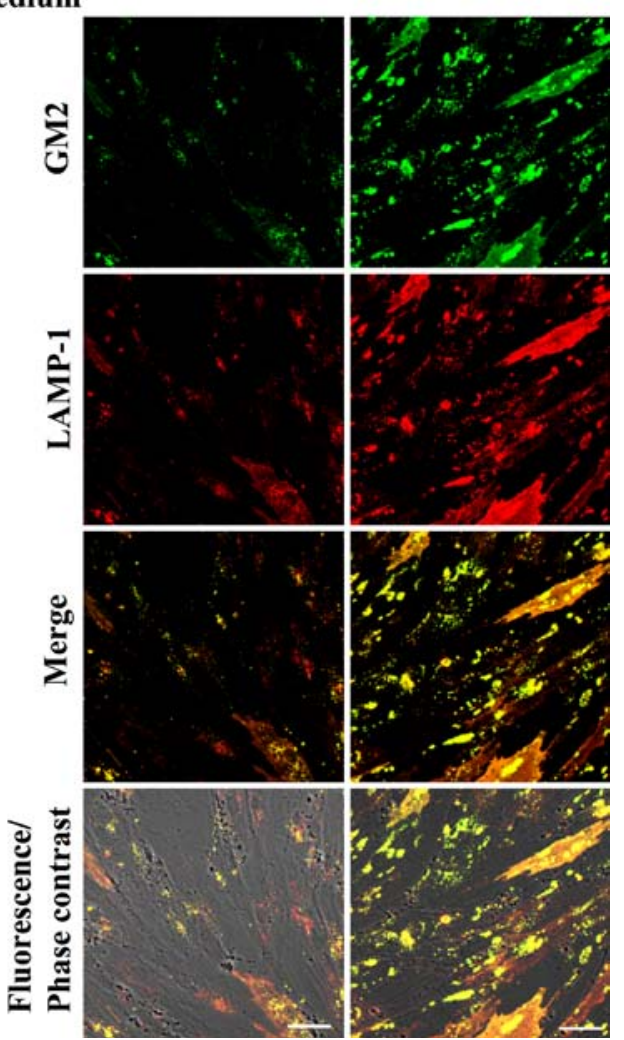

of these cells was carried out with a monoclonal antibody for GM2 ganglioside $(G M 2$, green) and polyclonal antibodies for LAMP-1 (LAMP-1, red). Fluorescence/Phase contrast images with these two fluorescent probes are shown in yellow. Some experiments were performed in the presence of $5 \mathrm{mM}$ M6P. Bars, $50 \mu \mathrm{m}$ 
human Sandhoff fibroblasts. Incorporation of the Hex isozymes was inhibited in the presence of $5 \mathrm{mM}$ M6P in the culture medium, indicating that these Hex isozymes are taken up via cation-independent M6P receptors on the surface of cultured Schwann cells and cultured fibroblasts. Hex isozymes are known to be synthesized in the rough endoplasmic reticulum and are modified through the addition of high-mannose oligosaccharides. The Hex isozymes are transferred to the Golgi apparatus where further modification, including the addition of M6P residues to the nonreducing ends of the sugar chains and binding to the cation-independent M6P receptors, occurs. Then, the enzymes are transported to endosomes/lysosomes. In cultured fibroblasts, Hex isozymes are thought to be transported from the extracellular milieu to lysosomes through cation-independent M6P-receptor-mediated endocytosis (Kornfeld and Sly 2001). The recombinant Hex isozymes could also be incorporated into the cultured Schwann cells via cation-independent M6P receptors although the total number of cationindependent M6P receptors on the surface of cultured Schwann cells might be less than that on cultured fibroblasts.

The incorporated recombinant human Hex A degraded the accumulated GM2 ganglioside in the cultured mouse Sandhoff Schwann cells as well as in the cultured human Sandhoff fibroblasts. The enhanced immunofluorescence for LAMP-1 in these cells was normalized after the administration of Hex isozymes although an addition of M6P inhibited that. It suggests that the increased and enlarged lysosomes caused by the accumulation of GM2 ganglioside could be normalized by the uptake of Hex isozymes through cation-independent M6P receptors. This encourages us to develop ERT for Sandhoff disease although the problem of the blood-brain barrier and blood-nerve barrier must be solved in the near future.

In conclusion, we established immortalized Schwann cells from Sandhoff mice. The cells are useful for investigation and development of therapies for Sandhoff disease, i.e., we will be able to examine incorporation of a modified enzyme developed for therapy into neuronal cells using this cell line before performing an experiment with Sandhoff mice.

Acknowledgement We wish to thank Dr. Richard L. Proia (Section on Genetics of Development and Disease Branch, National Institute of Diabetes and Digestive and Kidney Disease, National Institutes of Health) for providing us with the Sandhoff mice. This work was partly supported by grants from CREST, JST, the Tokyo Metropolitan Government, the Japan Society for the Promotion of Science, the Ministry of Education, Science, Sports and Culture, and the Ministry of Health, Labor and Welfare of Japan.

\section{References}

Barton NW, Brady RO, Dambrosia JM, Di Bisceglie AM, Doppelt SH, Hill SC, Mankin HJ, Murray GJ, Parker RI, Argoff CE (1991) Replacement therapy for inherited enzyme deficiencymacrophage-targeted glucocerebrosidase for Gaucher disease. N Engl J Med 23:1464-1470
Dobrenis K, Joseph A, Rattazzi MC (1992) Neuronal lysosomal enzyme replacement using fragment $\mathrm{C}$ of tetanus toxin. Proc Natl Acad Sci USA 89:2297-2301

Eng CM, Guffon N, Wilcox WR, Germain DP, Lee P, Waldek S, Caplan L, Linthorst GE, Desnick RJ (2001) Safety and efficacy of recombinant human $\alpha$-galactosidase A replacement therapy in Fabry's disease. N Engl J Med 345:9-16

Gravel RA, Kaback MM, Proia RL, Sandhoff K, Suzuki K, Suzuki K (2001) The GM2 gangliosidoses. In: Scriver CR, Beaudet AL, Sly WS, Valle D (eds) The metabolic and molecular bases of inherited disease, 8th edn. McGraw-Hill, New York, pp $3827-$ 3876

Harmatz P, Whitley CB, Waber L, Pais R, Steiner R, Plecko B, Kaplan P, Simon J, Butensky E, Hopwood JJ (2004) Enzyme replacement therapy in mucopolysaccharidosis VI (MaroteauxLamy syndrome). J Pediatr 144:574-580

Klinge L, Straub V, Neudorf U, Voit T (2005) Enzyme replacement therapy in classical infantile Pompe disease: results of a tenmonth follow-up study. Neuropediatrics 36:6-11

Kornfeld S, Sly WS (2001) I-cell disease and Pseudo-Hurler polydystrophy: disorders of lysosomal enzyme phosphorylation and localization. In: Scriver CR, Beaudet AL, Sly WS, Valle D (eds) The metabolic and molecular bases of inherited disease, 8th edn. McGraw-Hill, New York, pp 3469-3482

Kotani M, Ozawa H, Kawashima I, Ando S, Tai T (1992) Generation of one set of monoclonal antibodies specific for a-pathway ganglio-series gangliosides. Biochim Biophys Acta 1117:97-103

Mirsky R, Jessen KR (1999) The neurobiology of Schwann cells. Brain Pathol 9:293-311

Muenzer J, Lamsa JC, Garcia A, Dacosta J, Garcia J, Treco DA (2002) Enzyme replacement therapy in mucopolysaccharidosis type II (Hunter syndrome): a preliminary report. Acta Paediatr 91(Suppl):98-99

Phaneuf D, Wakamatsu N, Huang JQ, Borowski A, Peterson AC, Fortunato SR, Ritter G, Igdoura SA, Morales CR, Benoit G, Akerman BR, Leclerc D, Hanai N, Marth JD, Trasler JM, Gravel RA (1996) Dramatically different phenotypes in mouse models of human Tay-Sachs and Sandhoff diseases. Hum Mol Genet 5:1-14

Sakuraba H, Matsuzawa F, Aikawa S, Doi H, Kotani M, Lin H, Ohno K, Tanaka A, Yamada H, Uyama E (2002) Molecular and structural studies of the GM2 gangliosidosis 0 variant. J Hum Genet 47:176-183

Sakuraba H, Sawada M, Matsuzawa F, Aikawa S, Chiba Y, Jigami Y, Itoh K (2005) Molecular pathologies and enzyme replacement therapies for lysosomal diseases. Curr Drug Targets CNS Neurol Disord (in press)

Sango K, Yamanaka S, Hoffmann A, Okuda Y, Grinberg A, Westphal H, McDonald MP, Crawley JN, Sandhoff K, Suzuki K, Proia RL (1995) Mouse models of Tay-Sachs and Sandhoff diseases differ in neurologic phenotype and ganglioside metabolism. Nat Genet 11:170-176

Sango K, Yamanaka S, Ajiki A, Tokashiki A, Watabe K (2002) Lysosomal storage results in impaired survival but normal neurite outgrowth in dorsal root ganglion neurons from a mouse model of Sandhoff disease. Neuropathol Appl Neurobiol 28:23-34

Schiffmann R, Murray GJ, Treco D, Daniel P, Sellos-Moura M, Myers M, Quirk JM, Zirzow GC, Borowski M, Loveday K, Anderson T, Gillespie F, Oliver KL, Jeffries NO, Doo E, Liang TJ, Kreps C, Gunter K, Frei K, Crutchfield K, Selden RF, Brady RO (2000) Infusion of $\alpha$-galactosidase A reduces tissue globotriaosylceramide storage in patients with Fabry disease. Proc Natl Acad Sci USA 97:365-370

Suzuki K (1987) Enzymatic diagnosis of sphingolipidoses. Methods Enzymol 138:727-762

Van den Hout JM, Kamphoven JH, Winkel LP, Arts WF, De Klerk JB, Loonen MC, Vulto AG, Cromme-Dijkhuis A, Weisglas-Kuperus N, Hop W, Van Hirtum H, Van Diggelen OP, Boer M, Kroos MA, Van Doorn PA, Van der Voort E, Sibbles B, Van Corven EJ, Brakenhoff JP, Van Hove J, 
Smeitink JA, de Jong G, Reuser AJ, Van der Ploeg AT (2004) Long-term intravenous treatment of Pompe disease with recombinant human alpha-glucosidase from milk. Pediatrics 113:e448-457

Watabe K, Yamada M, Kawamura T, Kim SU (1990) Transfection and stable transformation of adult mouse Schwann cells with SV-40 large T antigen gene. J Neuropathol Exp Neurol 49:455467

Watabe K, Fukuda T, Tanaka J, Toyohara K, Sakai O (1994) Mitogenic effects of platelet-derived growth factor, fibroblast growth factor, transforming growth factor- $\beta$, and heparinbinding serum factor for adult mouse Schwann cells. J Neurosci Res 39:525-534

Watabe K, Fukuda T, Tanaka J, Honda H, Toyohara K, Sakai O (1995) Spontaneously immortalized adult mouse Schwann cells secrete autocrine and paracrine growth-promoting activities. J Neurosci Res 41:279-290
Watabe K, Ida H, Uehara K, Oyanagi K, Sakamoto T, Tanaka J, Garver WS, Miyawaki S, Ohno K, Eto Y (2001) Establishment and characterization of immortalized Schwann cells from murine model of Niemann-Pick disease type C (spm/spm). J Peripher Nerv Syst 6:85-94

Watabe K, Sakamoto T, Kawazoe Y, Michikawa M, Miyamoto K, Yamamura T, Saya H, Araki N (2003) Tissue culture methods to study neurological disorders: establishment of immortalized Schwann cells from murine disease models. Neuropathology 23:68-78

Wraith JE, Clarke LA, Beck M, Kolodny EH, Pastores GM, Muenzer J, Rapoport DM, Berger KI, Swiedler SJ, Kakkis ED, Braakman T, Chadbourne E, Walton-Bowen K, Cox GF (2004) Enzyme replacement therapy for mucopolysaccharidosis I: a randomized, double-blinded, placebo-controlled, multinational study of recombinant human alpha-L-iduronidase (laronidase). J Pediatr 144:581-588 